\title{
Editorial
}

\section{New Directions and Challenges in Histories of Health, Healing and Medicine in South Africa}

This Special Edition of Medical History is the first in this journal's fifty-seven years' history solely dedicated to histories of medicine, health and healing in South Africa, or indeed any African region. With one exception, the six articles featured here were presented at a workshop held in KwaZulu-Natal, South Africa in August 2012, under the broad (and often shifting) umbrella theme of 'New Directions in the Histories of Health, Healing and Medicine in African Contexts'. Hosted by ourselves, it was co-organised and supported by Professor Sanjoy Bhattacharya and the Centre for Global Health Histories, University of York, ${ }^{1}$ with financial support from the Wellcome Trust.

The Workshop's main objectives were to bring together - for in-depth discussions - scholars working on histories of health, healing and medicine in Africa, and more especially Southern Africa; to share works-in-progress and proposals for future research projects and publications; to support the emergence of upcoming senior graduate students from institutions based in Southern Africa; to position Southern Africa as a full partner in knowledge exchange, especially in the field of historical research; and to promote stronger partnerships between international and Africa-based scholars of health and medicine, and to discuss the formation of a network of medical historians, with regular meetings (perhaps biennially), to be held at venues in the Southern African region.

In publishing this edition in 2014, it also seems an opportune moment to consider how, twenty years into its democratic dispensation, South Africanists are continuing to think and write about earlier debates and central concerns in the histories of health, healing and medicine, perhaps looking at them in new ways; and also to underscore how historically informed analyses may add insights to newer circumstances in twenty-first century South Africa.

Over the past several decades, the international field of medical histories of the African continent has been growing steadily. Indeed, it can now be confidently asserted that scholarly investigation of the histories of medicine, health, healing and myriad related issues has become an essential lens through which to analyse and understand African regions, both past and present. In recent years, diverse subjects have been studied. Most notably, historical analyses have moved beyond consideration of homogenous or one-sided coloniser versus colonised healing encounters, or the celebratory triumphs of western medicine, to investigations of the critical limits and tensions produced by biomedicine

\footnotetext{
1 The authors extend their heartfelt thanks to the Editor of Medical History, Professor Sanjoy Bhattacharya, and to the Assistant Editor, Dr Alexander Medcalf, as well as to those at the University of York, especially Ms Ruth Gibson, and at the Wellcome Trust who assisted in the financial sponsorship (Wellcome Trust grant code: WT099719MA) of the workshop held in KwaZulu-Natal, South Africa, 19-21 August 2012, which gave rise to this special edition.
} 
in colonial and post-colonial situations. ${ }^{2}$ An exploration of a wide range and diversity of healing systems, as well as medical pluralism that has been practiced across healing 'traditions', have also been key features of recent research on health and healing in Africa. ${ }^{3}$ Furthermore, interdisciplinary work, as well as research utilising a broader analytical lens of global interactions, has pushed academic boundaries, and enlarged the audience and impact of the field. ${ }^{4}$

The contribution of Africa-based researchers and scholars, particularly those residing in South Africa, to these debates has been significant too. In her 2008 historiographical review, medical historian Anne Digby noted that there has been a 'rapidly growing historiography (that) has been influenced both by general literature in the history of medicine as well as by the more specific context of South Africa' ${ }^{5}$ Furthermore, colonial and post-colonial pasts, she argues, 'have shape[d] the present to an unusual extent and the legacy both of apartheid and of an ongoing democratic transformation impact on the historian's choice of subject'. These contexts mean that for those writing about South Africa from within this region, our historical writing on health and healing topics has often continued to be driven by an ongoing engagement with pressing (if not intensifying) sociopolitical and health-related issues, HIV/AIDS being the most obvious example. These publications have included, inter alia, social histories of particular regions; institutional studies of hospitals and medical training facilities; the work of various healthcare professionals; social medicine and community and public health; studies of various epidemic diseases; and innovative health-care activist movements; indigenous medicine, as well as what Digby calls 'the cross-overs and hybridisation between biomedicine and indigenous medicine' ${ }^{6}$

2 Shula Marks, 'Presidential Address: What is Colonial about Colonial Medicine? And What has Happened to Imperialism and Health?' Social History of Medicine 10, 2 (1997), 205-19; Frederick Cooper, 'Conflict and Connection: Rethinking Colonial African History', The American Historical Review, 99, 5 (December 1994), 1516-45; and Frederick Cooper and Anne Laura Stoler (eds), Tensions of Empire: Colonial Cultures in a Bourgeois World (Berkeley, Los Angeles and London: University of California Press, 1997).

3 The literature is too vast to be adequately listed here, but see, for example, Charles M. Good Jr, The Steamer Parish: The Rise and Fall of Missionary Medicine on an African Frontier (Chicago and London: The University of Chicago Press, 2004); Susanne M. Klausen, Race, Maternity and the Politics of Birth Control in South Africa (Houndmills, Basingstoke: Palgrave Macmillan, 2004); Anne Digby, Diversity and Division in Medicine: Health Care in South Africa from the 1800s (Oxford and Bern: Peter Lang, 2006); Tracey L. Luedke and Harry G. West (eds), Borders \& Healers: Brokering Therapeutic Resources in Southeast Africa (Bloomington and Indianapolis: Indiana University Press, 2006); David Hardiman (ed.), Healing Bodies, Saving Souls: Medical Missions in Asia and Africa (Amsterdam and New York:Rodopi, 2006); Markku Hokkanen, Medicine and Scottish Missionaries in the Northern Malawi Region 1875-1930 (Lewiston, Queenston and Lampeter: The Edwin Mellen Press, 2007); Karen E. Flint, Healing Traditions: African Medicine, Cultural Exchange, and Competition in South Africa, 1820-1948 (Pietermaritzburg: UKZN Press and Athens, OH: Ohio University Press, 2008); Claire L. Wendland, A Heart for the Work: Journeys through an African Medical School (Chicago and London: University of Chicago Press, 2010); Tiffany F. Jones, Psychiatry, Mental Institutions and the Mad in Apartheid South Africa (New York: Routledge, 2012) and Simonne Horwitz, Baragwanath Hospital Soweto: A History of Medical Care 1941-1990 (Johannesburg: Wits University Press, 2013).

${ }^{4}$ Maureen Malowany, 'Unfinished Agendas: Writing the History of Medicine of Sub-Saharan Africa', African Affairs 99, 395 (2000), 340-8; Nancy Rose Hunt, 'Suturing New Medical Histories of Africa' (University of Basel: Carl Schlettwein Lecture, 2011), and Lyn Schumaker, 'History of Medicine in Sub-Saharan Africa' in Mark Jackson (ed.), The Oxford Handbook of the History of Medicine (Oxford and New York: Oxford University Press, 2011), 275-9.

5 Anne Digby, 'The Medical History of South Africa: An Overview', History Compass, 6, 5 (2008), 1194.

${ }^{6}$ Just to mention book manuscripts by those situated within the historical profession, see, for example, Harriet Deacon, Howard Phillips and Elizabeth van Heyningen, The Cape Doctor in the Nineteenth Century: A Social History (Amsterdam: Rodopi, 2004); Julie Parle, States of Mind: Searching for Mental Health in Natal and Zululand, 1868-1918 (Pietermaritzburg: UKZN Press, 2007); Anne Digby and Howard Phillips, with Harriet 
In relation to the number of scholars - from multiple disciplines - working in the broad area of African histories of medicine, the number of such historians working at, and thus supported by, African academic institutions - is small, however. Nor is it usually possible for African historians to teach within their areas of speciality only. ${ }^{7}$ There are also significant 'global asymmetries' or challenges that have hindered development of professional networks and discussion fora within the region. ${ }^{8}$ Indeed, as is the situation with African studies more generally, the vast majority of those researching, writing, and reading African medical histories are based outside of the continent. ${ }^{9}$ As Parle has discussed elsewhere, this has problematic epistemological, material and political significance for the ability of African-based historians to gain intellectual authority within the profession of history, and within the academy, in the continent, as well as internationally. ${ }^{10}$

We certainly do not mean to suggest that medical history scholarship based outside of this region is invalid or compromised: on the contrary, it has often been that having an institutional and political vantage point from outside of the continent that has been essential for critical work to be done, including by those who went into exile as both academic and personal freedoms were threatened under the apartheid regime. Many of them not only continued their academic activism by producing searing critiques of racial capitalism, gender and class inequalities and the ideological and practical perversions of 'science' in colonial and apartheid era South Africa, but they made significant contributions to world historical debates. ${ }^{11}$

South African scholars of health and medicine based outside of the country were also able to participate, especially from the 1970s onwards, in an academic environment where the professionalisation of the study of medicine had already taken firm root, not least through the many national associations of historians of medicine and their journals. The subsequent generations of historians of medicine and related topics on the African continent trained at as well as based in the Global North are in many ways the fortunate

Deacon and Kirsten Thomson, At the Heart of Healing: Groote Schuur Hospital, 1938-2008 (Johannesburg: Jacana, 2008); Howard Phillips, Plague, Pox and Pandemics: A Jacana Pocket History of Epidemics in South Africa (Johannesburg: Jacana, 2012); Julie Dyer, Health in Pietermaritzburg: A History of Urbanisation and Disease in an African City, 1838-2008 (Pietermaritzburg: Natal Society Foundation, 2012); Mandisa Mbali, South African AIDS Activism and Global Health Politics (Houndmills, Basingstoke: Palgrave Macmillan, 2013) and Vanessa Noble, A School of Struggle: Durban's Medical School and the Education of Black Doctors in South Africa (Pietermaritzburg: UKZN Press, 2013).

7 At a generous estimate, for instance, there are probably no more than 200 professional historians employed at Southern African universities. In 2012 and 2013 the entire History programme - from first year to PhD level - at UKZN on the Pietermaritzburg campus was taught by the discipline's only four members of staff, with no graduate student or tutor support. At the end of 2013, two of those staff members resigned from UKZN, and they have not been replaced.

8 Schumaker, 'History of Medicine in Sub-Saharan Africa', 280. Also see Malowany, 'Unfinished Agendas', 325-6.

${ }^{9}$ See Shamil Jeppie, 'Africa: whose history? whose memory?', in Jeppie, (ed.) Toward New Histories for South Africa, On the Place of the Past in Our Present (Landsdowne: Juta Gariep, 2004), 21-22.

10 Julie Parle, “"The past and its possibilities”: perspectives of Southern Africa', South African Historical Journal, 64, 2 (2012), 159-69.

11 To identify but a few of the most influential of these, one might mention (in alphabetical order) Jean and John Comaroff, Saul Dubow, Norman Etherington, Shula Marks. Cambridge economic historian, Charles Feinstein, until his passing in 2004, was the partner of Anne Digby, a distinguished medical historian. After returning on a seasonal basis to South Africa after 1994, Digby has become a prolific contributor to South African medical histories. The collected works of these South-African-born scholars and those by their students is too extensive for this editorial. To such a list could also be added the writings of emigrant physicians and so on, such as Sidney and Emily Kark and many others. 
inheritors of this early diaspora of a small, but very influential, group of South Africanist historians. Moreover, there is also now an international academic environment richly endowed with professional associations, conferences, research units and journals dedicated to the history of medicine and health.

For those of us researching, teaching and living in Southern Africa, however, there are somewhat different material, institutional, political and pedagogic factors at play. And while the need for critical engagement of historians with the current inequalities of the region's healthscape remains no less pressing than in the past, there is as yet no professional association of historians of health; nor is there any unit or research wing of a university or other organisation dedicated specifically to the study of the histories of health, medicine and healing in South Africa. Rather, historians working on topics related to the histories of health, healing or medicine in Africa have tended to meet at general history conferences, where placement on panels on medical themes have brought them into conversation, or at international medical history-themed conferences or workshops, where they have forged often mutually beneficial professional, academic and resource linkages with international scholars in the Global North, most especially in the United Kingdom, Europe and North America.

In South Africa, historians are making their mark in several important inter-disciplinary and trans-national projects, such as that anchored by scholars at WiSER (the University of the Witwatersrand's Institute for Social and Economic Research) and the Primary Health Care Directorate at the University of Cape Town who are working at 'developing medical humanities in Africa' and, who in September 2013, hosted the continent's first conference on this knowledge field. ${ }^{12}$ They have also - just recently - been successful in gaining a seed grant from South Africa's National Research Foundation to establish the field as one that will in future qualify for grant applications.

The need for inter-disciplinary and transnational collaborative scholarship is clear, yet in amongst the myriad possibilities, arguably, there is the danger of losing the particular skills and insights that discipline specialists, such as historians, can bring to bear. On the other hand, historians need themselves to be attuned to the constantly shifting contexts in which we work and the rising of new situations to which we can bring our own, hard-won perspectives. For instance, contemporary challenges include the changing demographic and healthscapes of a country that has recently embarked on the large scale state-sponsored provision of anti-retroviral treatments (ARVs) for HIV/AIDS, even while the leading causes of morbidity and mortality remain, as they have since the nineteenth century, 'certain infections and parasitic diseases, particularly tuberculosis, (but now including) MDR-TB and XDR-TB' ${ }^{13}$ In addition, at the same time that poverty and gender-based violence remain as disturbingly widespread as ever, obesity and type 2 diabetes, those conditions often associated with the 'nutrition and epidemiological transitions' are on the rise as transnational capitalism floods our markets with imported foods to a greater extent than ever before.

Already observable, although as yet perhaps too early to be analysed is the context of the retraction or reorientation over the past five or so years of international funding

12 'Body Knowledge: Medicine and the Humanities in Conversation', conference hosted by WiSER at the Witwatersrand School of Public Health, convened by Catherine Burns and Ashlee Masterson. See http://wise r.wits.ac.za/page/body-knowledge-conference-programme-10976 (last accessed 6 January 2014).

13 'Mortality and Causes of Death in South Africa, 2010. Findings from Death Notification', report by Statistics South Africa, 16, and found at http://www.statssa.gov.za/publications2/P03093/P030932010.pdf (last accessed 6 January 2014). 
of HIV/AIDS programmes. This is leading to the redirection of associated monies, expertise and priorities from the non-governmental (NGO) health sector that has been absolutely central to struggles to force late apartheid and early democratic South African governments to take the pandemic seriously. The Department of Health is now committed to implementing a National Health Insurance scheme that will greatly extend public health access, yet it must attempt to bring this about at a time when many existing state hospitals remain notoriously poorly resourced. In addition, many of the most highly skilled medical, clinical and nursing personnel have left our shores in the international diaspora of doctors and health-care workers.

In terms of legislation, we are also yet to solve the legal challenges posed by the need to regulate and resolve the apparent contradictions between biomedicine and indigenous therapeutics, although as recently as 2012, the Interim Traditional Health Practitioners' Council was eventually able to begin its work after a delay of nearly a decade. ${ }^{14}$ And, even since the adoption of one of the world's most progressive Constitutions guaranteeing the right of access to reproductive health, maternal, infant and child mortality rates remain unacceptably high and it has been shown too that the "continued preponderance of illegal abortions. . . is an enduring feature of South Africa's reproductive landscape'. ${ }^{15}$

And, perhaps least known of all is the extent to which psychiatric and mental health issues trouble individuals and communities in a massive, yet largely silent, shadow which darkens the lived experiences of millions of South Africans. According to a Report by the Mental Health and Poverty Project Consortium submitted to the South African Human Rights Commission in 2008-2009, it is estimated that there ' . . . is growing recognition that mental health is a crucial public health and development issue in South Africa... (the) latest reviews of disease burden in this country rank neuropsychiatric conditions 3rd in their contribution to the burden of disease, after HIV/AIDS and other infectious diseases'. ${ }^{16}$

Moreover, hospital and school facilities for both psychiatric patients and mentally challenged children are often ageing infrastructure, some of these buildings dating to the colonial era and yet to be significantly upgraded or replaced with new structures or treatment regimes. In short, in South Africa today, the impact of communicable diseases, ill-health, gender-based violence, poverty and factors such as high levels of alcoholism, increasing narcotics abuse, disability and violence, including road accident deaths, are continuing to place enormous strains on individuals and on families, especially women.

For historians of health and medicine this scenario, and the need to historicise their roots, is all too familiar, yet there are some novel features to this twenty-first century situation that, we felt required contemplation of new perspectives. Feeling the need to engage with other regionally based scholars on a regular basis in order to discuss our research agendas, sources and to hear each others' concerns, we decided in early 2012 to sound out, in an informal way, African-based academics as well as a number of others with whom we had recently worked. The initial idea was for an informal, self-funded one or two day gathering of a maximum of thirty persons on the Pietermaritzburg campus of the University of KwaZulu-Natal, where we were both then based. The first, cumbersome,

\footnotetext{
${ }^{14}$ See http://www.doh.gov.za/show.php?id=3919 (last accessed 23 December 2013).

15 Rebecca Hodes, 'Abortion politics in post-apartheid South Africa', unpublished chapter in forthcoming publication with Tracy Penny Light and Shannon Stettner; draft chapter generously shared with us by the author. ${ }^{16}$ Sarah Skeen, Crick Lund, Sharon Kleintjes and Alan Flisher, 'Mental Health and Poverty Project', Submission South African Human Rights Commission Public Hearings on the Millennium Development Goals and the realisation of Economic and Social Rights in South Africa', 2. Undated document located at http://www.heal th.uct.ac.za/usr/health/research/groupings/mhapp/resources/SAHRC1.pdf (last accessed 6 January 2014).
} 
title for our meeting was 'New Directions in Histories of Health, Healing and Medicine in African Contexts' (or NDHHHMAC - an unlovely acronym, but one as yet that we have found impossible to refine successfully).

Coincidentally, at this juncture a request came from internationally renowned medical historian, Professor David J. Wright, to meet other historians of medicine during his short visit to South Africa in August 2012. ${ }^{17}$ Given the considerable distances between the major South African universities it seemed easier to get everyone together than for Wright to divide his time between the Cape, Johannesburg and KwaZulu-Natal. The first, exploratory email invitations went out in February and given that we had absolutely no budget or administrative assistance for this project, the immediate and positive response from many scholars was gratifying, underscoring the need for such a meeting. More than two dozen people undertook to find their own funding and organise their own travel to and lodging in Pietermaritzburg.

Fortunately, within weeks of our first invitations, Bhattacharya contacted us on another matter and discussion followed about possible funding options for our workshop. Bhattacharya suggested and encouraged a joint application to the Wellcome Trust for a Small Grant. The application was submitted in April 2012 and the Grant was subsequently awarded. It was agreed that Dr Sabine Clarke, a lecturer in Modern History, and a specialist in the history of science and technology in Britain and its colonies, would represent the History Department of the University of York at the workshop as part of this joint arrangement. With the success of the Small Grant application, we were able to secure a suitable workshop venue and onsite accommodation about $45 \mathrm{~km}$ from Pietermarizburg.

For many of us based in South Africa, this inaugural meeting of a network of people was the first time we had actually met each other despite years of reading each others' work; for others, it was the first time we had met in South Africa although we had met before in the United Kingdom, the USA and in Switzerland, for instance. ${ }^{18}$ For others whose institutional bases are elsewhere but whose professional interest lies in this region, even if they had already undertaken many research trips to South Africa, it was an opportunity to share in and contribute to robust, spirited and - a term used several times - passionately animated discussions about the value of histories of health, medicine and healing and the need for Africa-based scholars to contribute as full partners in knowledge exchange and resource development, especially in the field of historical research.

Building on from our initial invitation, papers were garnered from existing contacts, as well as specialists in African health histories. Eventually, twenty-six participants were able to attend, representing twelve universities, including those of Basel, California State, Cape Town, Carleton, KwaZulu-Natal, McGill, Pennsylvania, Queens, Rhodes, Stellenbosch, the Witwatersrand, and York.

${ }^{17}$ For much of his career, Wright has researched the history of mental disorders and mental hospital health care. His most recent book, Downs: The History of a Disability (Oxford: OUP, 2011) was awarded the 2013 Dingle Prize by the British Society of Science. He is now Professor of History at McGill University, Canada, with his appointment shared with the Institute for Health and Social Policy, Faculty of Medicine, at McGill.

${ }^{18}$ For the authors of this editorial, three intellectually-stimulating international workshops and conferences, which we participated in, come to mind: 'The History of the Hospital as a Biomedical and Social Institution in Africa', 3-6 January 2008, University of Basel, Switzerland; 'Imagining and Practicing Imperial and Colonial Medicine, 1870-1960', 10-12 January 2008, University of Oxford, UK; and 'Health Care in Africa: Actors, Experiences and Perspectives in the 20th Century', 12-13 September 2011, University of Basel, Switzerland. Two notable South-African-based conference exceptions included a conference organised by Catherine Burns in Durban and Pholela between 24 and 27 July 2000 entitled 'Social Medicine and Reform of the Health System in South Africa' and one organised by Howard Phillips at the University of Cape Town between 24 and 26 November 2008 entitled 'Hospital History in Africa: A Conference Spanning the Continent'. 
The majority of participants were from - and papers focused on - South Africa, and this is also true for this journal edition. There were however also papers on the transnational migration of health-care workers (David Wright, McGill); on Catholic medical missionaries in Nigeria, 1930s to 1970 (Barbra Mann Wall, Pennsylvania); on medical practice and patient photography in colonial Zimbabwe (Glen Ncube, UCT); on the (British) Medical Research Council and the politics of research in British colonial Africa after 1940 (Sabine Clarke, York); ${ }^{19}$ and on epilepsy, missionary medicine and transcultural psychiatry in Mahenge, Tanzania, from the 1940s to the present (Marcel Dreier, Basel).

Many conversations arose encompassing the comparisons, contrasts and common methodological challenges between these and the studies centred more specifically on South Africa. Ncube's paper in particular (which discussed the absence of historical analyses of African patient photography), ${ }^{20}$ which drew strongly on Megan Vaughan's important caveat that colonising Europeans perceived all Africans as 'Other', propelled us into animated consideration of how pre- and colonial era African self-representations in art, dance, stories and costume might, in future, be investigated as ways of glimpsing how indigenous imaginings of 'the Other' may have been reinforced, or changed, over the past two centuries or more.

Furthermore, two presenters were unfortunately obliged to withdraw from the workshop They were UKZN's Thokozani Xaba, whose earlier work on African traditional medicine, modernity and witchcraft (2000) remains an indispensable and accessible introduction to these themes that are connected in complicated, and sometimes disturbing, ways, was to have been extended in the proposed paper, 'Witchcraft, Sorcery or Medical Practice? Recent Developments in Post-Apartheid South Africa' ${ }^{21}$ The final paper in the programme would have been that by upcoming young historian, Mxolisi Mchunu, whose $2013 \mathrm{PhD}$ dissertation explored African oral histories of trauma and violence in the very KZN Midlands where we were meeting. Its title 'Nightmares, oral histories, trauma and violence in the KwaZulu-Natal Midlands of the 1980s and 1990s' points to the expanding interest of African historians in the intersections between the practice of history and personal and community healing as well as to a courageous willingness to begin to historicise the intraand inter-personal damage experienced by those living through the often bloody violence of the late apartheid era.

\section{The programme}

After two opening overviews, the programme was divided into seven panel sessions, with the following themes: 'Biomedicine in Africa: A Tool of Empire?'; 'Histories, Activists and Impacts'; 'Committals, Asylums and Patients'; 'The Politics of Abortion in South Africa'; 'Plagues, Wars, Hospitals and Health Politics in South Africa'; 'Shame, Minds,

19 See Cambridge University Press's Open Access article by Sabine Clarke entitled 'The Research Council System and the Politics of Medical and Agricultural Research for the British Colonial Empire, 1940-52', Medical History, 57, 3 (July 2013), 338-58, located at https://bbsonline.cup.cam.ac.uk/action/openAccessJournal?jid=M $\mathrm{DH}$.

20 Glen Ncube, NDHHHMAC paper, 'Problematising Camera Medica: Medical Practice and Patient Photography in Colonial Fort Victoria, Zimbabwe'.

21 Thokozani Xaba, 'Marginalised Medical Practice: The marginalisation and transformation of indigenous medicines in South Africa', at http://www.ces.uc.pt/emancipa/research/en/ft/triunfo.html (last accessed 6 January 2014). 
Bodies, Crimes'; and our final panel was termed "'Tribal” Diseases', a title we struggled with, but which is itself a comment on how Africans have often been portrayed - including by themselves - as having unique afflictions that mark 'them' as somehow 'different', as 'Other'.

The opening talks were given by established medical historians, Professors Howard Phillips of the University of Cape Town and David Wright. Phillips is the most eminent South African expert on the social history of medicine, especially epidemics and pandemics, medical education and hospital histories. His talk, 'Hippocrates and Historiography in South Africa: Historical Writing on Health, Disease and Medicine in South Africa since 1980', was a short, but profoundly stimulating survey of historical writing, teaching and scholarship on disease, medicine and health in Southern Africa. He also made an impassioned appeal for South African historians of medicine to make our work accessible, relevant and to have an impact, not least on largely politically-driven debates about the National Health Insurance scheme. His call for us to 'speak history to power' resonated throughout the following discussions.

Phillips also pointed to the many significant silences and gaps that remain in the South African medical historiography. Topics found wanting, in Phillips's estimation, included histories of professional medical associations, such as MASA, NAMDA and DENOSA; ${ }^{22}$ the impact of new medical technologies on the development of clinical medicine; and histories of auxiliary health-care providers, such as paramedics. Patient-centred histories, more histories of healing hybridities, ${ }^{23}$ and those of biomedical research and ethics, were also raised as research fields requiring attention, as do, he said, histories of lifestyle or non-communicable/chronic diseases; for, quoting one of South Africa's most renowned authors, Zakes Mda, Phillips reminded us that 'Our ways of living are our ways of dying. .. 24

While Howard Phillips is, along with Elizabeth van Heyningen (also present at the workshop, speaking on histories of nutrition, diet and food during the South African War) ${ }^{25}$ one of South Africa's veteran historians of health and medicine, David Wright's work is only recently extending to consider Africa, a continent which, as noted above, and as boldly expressed by Phillips 'is losing healthcare workers abroad hand over fist' in his work on the international movement of medical and nursing professionals. Wright's talk 'Global Health Histories and the Transnational Migration of Health Care Workers', ${ }^{26}$ complemented Phillips's pointer to the need to extend research into what might seem to be on the margins of general African medical histories. This because in addition to considering how developed nations such as Canada have benefited at the expense of sub-Saharan Africa, his talk was significant for another reason: his call for historians to adopt transnational approaches in their research and writing; and to study history from an interconnected, global perspective. For instance, as Wright illustrated, the '. . migration of

\footnotetext{
22 The acronyms MASA, NAMDA and DENOSA stand for: the Medical Association of South Africa, the National Medical and Dental Association and the Democratic Nurses Organisation of South Africa respectively. 23 See Flint, Healing Traditions, and Anne Digby and Helen Sweet, 'Nurses as cultural brokers in twentiethcentury South Africa' in Waltraud Ernst (ed.), Plural Medicine, Tradition and Modernity, 1800-2000 (London and New York: Routledge, 2001), 113-29.

24 Zakes Mda, Ways of Dying (New York: Picador, 1995).

${ }^{25}$ Elizabeth van Heyningen, The Concentration Camps of the Anglo-Boer War: A Social History (Auckland Park: Jacana, 2013).

26 David Wright, Nathan Flis and Mona Gupta, 'The "Brain Drain" of Physicians: Historical Antecedents to an Ethical Debate, c. 1960-1979', Philosophy, Ethics and Humanities in Medicine, 24, 3 (2008), located at http://www.peh-med.com/content/3/1/24 (last accessed 6 January 2014).
} 
hundreds of thousands of skilled medical personnel transformed the healthcare landscape of "recipient" and "source" countries'. ${ }^{27}$

It is not possible in an editorial of this length to adequately review each contribution to the workshop or to reflect sufficiently the vibrancy of the exchanges. Many of the papers not published here will surely soon appear in other publications and many of the graduate students who presented "think pieces" will in due course be producing their own dissertations, and subsequent monographs and journal articles. ${ }^{28}$ New exhibitions, collaborations and conferences have in fact already begun to flow from the bringing together in one place of this particular mix of people. ${ }^{29}$ Thus, in what follows we will try to highlight just some of the most significant foci of the discussions over the course of the workshop, by introducing and contextualising the six articles refined by their authors from August 2012 for this 2014 Special Edition.

The first article 'Reconstructing Harry: A genealogical study of a colonial family "inside" and "outside" the Grahamstown Asylum, 1888-1918' by Lindy Wilbraham is a richly layered paper that "pulls between two meanings and methods of "genealogy" in reconstructing patient and practitioner views, while also addressing involvement of family members in mental health care and stigma of mental illness'. Deploying a Foucaultian approach, 'Reconstructing Harry' brings together the multiple scattered extant accounts of the life, committal to a mental hospital, and memories of Harry Walter Wilbraham, the author's great-grandfather, whose bizarre behaviours led to him being medically boarded in 1906 from his position as Postmaster at the small town of Idutywa (now Dutywa), in the Eastern Cape. After being diagnosed with a 'disease of the brain', Harry Walter Wilbraham was admitted to the Grahamstown Asylum in March 1910 and died there, aged 40 , in October of the following year. ${ }^{30}$

Bringing together social and family history via a skein of theoretical layers, networks and webs of feelings, memories and texts, 'Reconstructing Harry' dovetails and extends existing South African histories of mental illness, both 'inside' and 'outside' the asylum in the late nineteenth to mid-twentieth centuries, particularly those of settlers. The disgrace, difficulties and stigma, as well as the financial, consequences of committal to a colonial lunatic asylum for whites are now being woven into richer tapestries of colonial life than

\footnotetext{
27 The extent to which transnational histories are actually new is a matter of dispute amongst - perhaps different generations of - historians. At the 2011 Basel conference and in her paper at a 2013 WiSER Seminar for instance, Shula Marks pointed out that the histories of social-based medicine, with which she has been closely involved over the past several decades, have always been international, global or transnational. For just one recent comment on the challenges of thinking and writing 'global' medical histories, see Sarah Hodges, 'Second Opinion: The Global Menace', Social History of Medicine, 25, 3 (2011), 719-28.

28 Workshop papers or 'think pieces' not directly discussed or otherwise cited in this article were given by Prinisha Badassy, “In a Fit of Mental Derangement”: Medico-Legal Discourses of Puerperal Insanity and Infanticide, Natal, 1890-1920'; Mary Caesar, 'The Local Health Commission and the "Modern Concept of (Public) Health" in Natal, 1935-1947’; Tiffany F. Jones, 'The Psychiatrization of Criminality and the Criminality of Madness: Re-Interpreting Forensic Psychiatric Abuses in the Context Apartheid South Africa', Radikobo Ntsimane, 'Prevention and Not Cure is the Miracle: A Critical Study of the Development of Health Provision in the Nazareth Baptist Church in the Early Twentieth Century Natal and Zululand (A Preliminary Investigation)'; and Kyla O'Neill, 'Seeking in Silence: The Challenges of Writing the Recent History of Intersexuality in South Africa from 1950-the Present'.

29 Although not initiated at this workshop, academic collaborations were facilitated by the space opened up on this occasion. For example, Vanessa Noble and Marcel Dreier (a Swiss-based historian), were able to co-present a 'think piece' for their - at that stage new joint research project - entitled 'Becoming Nonkunzi: The Swiss Doctor Maria Kunz and Healthcare in the Eastern Cape, South Africa, 1930s-1980s' at this workshop.

30 Originally known as the Fort England Asylum, and similar to several others in the region, it was originally used as a military barracks. There is still a psychiatric hospital on the same site today, with around 300 patients.
} 
earlier images of a homogenous privileged class, as well as of colonial asylums as being merely places for the confinement of 'the African insane' ${ }^{31}$ It raises, too, complex ethical questions for Wilbraham as a professional psychologist, a historical researcher, and a descendant of Harry; and the paper is a thought-provoking reflection on the privileges and perils of what a person who is positioned as a broker with a "number of hats", might discover when we go 'digging' in the archives.

The panel in which 'Reconstructing Harry' was presented was notable in that it was the first on the history of psychiatry in South Africa to be given at a South African medical history conference or workshop, though, clearly, individual papers have been presented on the broad theme at local seminars and conferences with broader purviews. All three papers were by scholars - two of whom are psychologists by profession - working on histories of Cape mental hospitals. The papers complemented each other. For instance, Rhodes University PhD candidate Kylie van Zyl's paper examined masculinity and white patients in the Grahamstown Asylum between 1875 and 1920, thus, during the years of Harry's own time spent there. ${ }^{32}$ UCT's Sally Swartz's paper, titled 'Certified Insane: The Machinery of the Committal Process', was concerned with the challenges to magistrates and other officials in the Cape between the late 1800s and early 1900s in implementing the Colony's 'Lunacy Laws'. Once again, what came through was an amplification of the works of historians such as Shula Marks and Felicity Swanson in contesting early historiographies. Simplistic models of 'social control' operated 'from above' by the state were complicated by 'the complex interface between families, resident magistrates, district surgeons' and 'the law', as well as those with the often impossible task of enforcing it. ${ }^{33}$

Not only did the papers in this and other panels that were concerned with psychiatry, and archival methodology encourage us to wander away from, to use Wilbraham's term, the 'well-worn paths' of research in this area in Southern Africa and link to those being travelled elsewhere (via interfacing with works on the social history of mental illness, settler colonialism and 'whiteness', as far afield as Canada and New Zealand, for instance). They also returned us again to the issue of the ethics of historical research: Why do we do what we do? What is its value? How do we make it relevant in the present? And what are our ethical responsibilities to both the living, and the dead?

These questions were central to a 'think piece' presented by Parle, entitled 'Relevance, Responsibility and Ethical-Activist Research in South African Medical Histories', which asked us to discuss the methodological, ethical, professional - and legal - issues to be considered in the use by historians of patient records, and other records that contain medical information, and how we should use them. These issues are certainly not unique to

\footnotetext{
31 This literature too is now extensive. Some examples are Robert Edgar and Hilary Sapire, African Apocalypse: The Story of Nontetha Nkwenkwe, a Twentieth-Century South African Prophet (Athens, Ohio and Johannesburg: Ohio University Press, 1999); Alexander Butchart, The Anatomy of Power: European Constructions of the African Body (London: Zed Books, 1998); Shula Marks, “"Every Facility that Modern Science and Enlightened Humanity have Devised": Race and Progress in a Colonial Hospital, Valkenberg Mental Asylum, Cape Colony, 1984-1910' in Joseph Melling and Bill Forsythe (eds), Insanity, Institutions and Society, 1800-1914: A Social History of Madness in Comparative Perspective (London: Routledge, 1999), 268-91; Felicity Swanson, 'Of Unsound Mind': A History of Three Eastern Cape Mental Institutions, 1875-1910 (unpublished Masters dissertation, Department of Historical Studies, University of Cape Town, 2001); Tiffany F. Jones, Psychiatry, Mental Institutions, and the Mad in Apartheid South Africa, op. cit. See also Sally Swartz, 'Colonial Lunatic Asylum Archives: Challenges to Historiography', Kronos 34, (2008), 285-302.

32 Kylie Van Zyl, NDHHHMAC Workshop paper, '(Un)fortunate Sons? Constructing "Masculinity" in the Grahamstown Asylum'.

${ }^{33}$ Sally Swartz, NDHHHMAC Workshop paper, 'Certified Insane: The Machinery of the Committal Process', Abstract.
} 
South Africa, but prompted in part by Parle's then recent appointment to the South African National Archives Advisory Council, and tasked with the redrafting of national legislation that will ensure the preservation - or the destruction - of medically-related materials.

There are no conclusive answers to these questions, but with the issue having been aired at a number of different fora, museologists, archivists and historians are becoming increasingly engaged in critiquing South Africa's archival and heritage legislation and seeking to refine the definition of what ought to be preserved - and destroyed - in enabling current day and future historians (including those who will wish to work with documents due to be declassified from 2014 which will illuminate post-1994 state decisions and perhaps even cover-ups on health-related matters) to 'speak history to power' ${ }^{34}$

A somewhat different set of challenges and questions is raised in the second paper, authored by Vanessa Noble and Julie Parle, on the topic of the relevance for today of the history of a single hospital and to use Guenter B. Risse's well-known phrase, its particular 'organisational culture'. "The Hospital was just like a Home": Self, Service and the McCord Hospital Family', arises from a broader work (along with third coauthor, Catherine Burns) covering the history of a missionary hospital in Durban, from its foundations and opening in 1909 through to 2009. In proportion to its institutional size, McCord Hospital has played a vastly significant part in the development of medical education - both for nurses and for doctors - across the Southern African region. Founded by members of the Congregationalist American Board of Commissioners for Foreign Missions, James Bennett and Margaret Mellen McCord, the hospital was for a long time the only one dedicated to black African patients in an urban area in KwaZulu-Natal. Over the years, its funding diversified, and was derived from subsidies from the state, patient fees, and donations from private individuals and business people from different 'race' groups. As a partly private, partly state-funded institution, it faced financial uncertainty, hostility from white settler neighbours, and the repeated threat of closure or removal from the 'whites only' zone under which it fell during the apartheid era. That McCord 'Zulu' Hospital (as it was formally known until recently) continued to survive was the consequence of a number of factors, personalities, deals, local politics and shrewd management. Bridgman Memorial Hospital for Non-European Women in Johannesburg, which had also been founded in 1928 by American Board missionaries, as Catherine Burns has described, did not. Instead, Bridgman was forcibly closed in 1965 and all black patients were then obliged to attend to Baragwanath Hospital. ${ }^{35}$

'The Hospital Was Just Like a Home', focuses on another important aspect of the hospital's longevity and particular character: the ethos of a 'McCord Family', integral to which were faith and a commitment to service. While on one level this term is ubiquitous in institutional hospital histories, perhaps even banal, we discuss how the notion of 'a McCord family' was experienced and shared in complex ways. Whilst recognising that 'hospital families' such as that at McCord are contentious social constructs, with deeply embedded hierarchies and inequalities based on race, class and gender, we argue that this 'family ethos' did considerable 'work' for this mission hospital, especially in promoting multi-racialism in the contexts of segregation and apartheid.

\footnotetext{
${ }^{34}$ See Rochelle Keene and Julie Parle, 'Museums, Archives and Medical Material: Some Ethical Considerations', forthcoming in the South African Museums Association Bulletin; see also David Wright and Renée Saucier, 'Madness in the Archives: Anonymity, Ethics, and Mental Health History Research', Journal of the Canadian Historical Association, 23, 2 (2012), 65-90.

35 From the NDHHHMAC workshop, see Catherine Burns, 'The History and Politics of Women's Health in South African Hospitals: A Comparison between the Bridgman Memorial Hospital for Non-European Women and McCord Hospital'. Also Horwitz, Baragwanath Hospital Soweto, op. cit.
} 
Between the writing of our article in 2011 and the end of 2012, McCord Hospital has again faced new circumstances. International donor funding - particularly from the USA - has shifted away from smaller institutions such as McCords, towards the South African government and the commitment by the state to make ARVs a component of a comprehensive public health service, based in many areas on newly constructed modern facilities. Unwilling to charge its largely working class patients higher fees, the hospital has teetered on the edge of closure for the past eighteen months or more. As historians, we have been pulled into the campaigns - by the hospital, by local community groups and on occasion by the media - to provide historically weighted reasons why McCords' should continue to receive state funding. Whether our arguments, that McCord has managed to provide an important 'third way' - a hospital that was state-aided but not state-controlled - enabled it to withstand prejudiced apartheid era bullies and post-apartheid era AIDS denialists alike may have had some impact, remains to be seen. Either way, it is immensely poignant that on the Hospital's Facebook page and in newspaper and radio programmes, very many patients as well as current and former staff continue to speak of the hospital in terms of it 'being home'.

Susanne M. Klausen's paper is drawn from her forthcoming book on the social, political and cultural aspects of abortion, birth control and nationalism in apartheid South Africa, largely before the 1980s. It dovetailed therefore well with that by Rebecca Hodes, 'The Medical History of Abortion in South Africa, c. 1970-2000', and the shorter reflection paper in the same panel by then UKZN Honours student Chris Eley, 'Speaking for and Speaking of Women: Looking for "Voice" in Abortion and Reproductive Health Debates'. Klausen's broader work highlights how from the mid-1970s, the National Party-led government 'established a gendered population control program in a bid to curb (African) population growth'. The African National Congress-led liberation movement's national liberation struggle however 'was largely silent or hostile to black women's attempts to control their (own) reproductive sexuality'. Thus, both Afrikaner and African masculinist politics shared a "heteropatriarchal worldview that was hostile to "their women" asserting control over their bodies'. The consequences for this, she argued, are evident today in the continued high incidence of black women's recourse to clandestine abortion, even under a constitutional dispensation that permits legal termination of pregnancies.

Since Klausen covered a wide timescale in her presentation for the Workshop, in her submission for this publication, 'The Trial the World is Watching: The 1972 Prosecution of Derk Crichton and James Watts, Politics of Abortion, and Regulation of the Medical Profession in Apartheid South Africa' she agreed to focus on one aspect of this important history: the relationship between racist state agendas of the control of reproduction, abortion and the policing of women who were classified as 'white'. Crichton was an eminent English-speaking obstetrician whilst Watts, from a lower socio-economic group, was a 'self-taught abortionist'. Klausen's telling of how they were persecuted and prosecuted by the state sheds some light on the difficult-to-access stories of the many thousands of South African women from all racial, ethnic and economic backgrounds who sought 'back street' or clandestine abortions in a highly repressive context, as well as conflicting attitudes towards the legalisation of the practice. As Klausen illustrates, their trial, and the attention given to the policing of whites' sexuality, must be understood against the intensifying conservatism of the South African state in the context of the Cold War era and the hardening of anti-apartheid international politics in the years just before the Soweto Uprisings of 1976. 
The political divisions between South African medical professionals, and the complicity - if not direct involvement - of some of them in gross human rights abuses during this time period, and the failure of international health organisations to, at the very least, effectively censure South African health professionals and the largely ineffectual Medical Association of South Africa (MASA) is described in some detail by Mandisa Mbali, in her article " A Matter of Conscience": The Moral Authority of the World Medical Association and the Readmission of the South Africans, 1976-1994'. Rather than merely repeating the many (fully warranted) condemnations of the role of two South African doctors who failed to attend to the fatally injured Black Consciousness leader, Steve Biko, as he was kept in police detention and then transported hundreds of kilometres to another detention centre, where he died on 12 September 1977; or on the well-known presentations made by health professionals to South Africa's famous Truth and Reconciliation Commission (TRC) in 1996-1998, Mbali's theoretical and analytical orientation is towards the broader stage of 'transnational anti-apartheid activism in South Africa, Britain and the United States'.

Once more, Cold War politics and alliances are crucial in understanding why MASA was readmitted to the World Medical Association (WMA) in 1981, after the former body had withdrawn itself from the WMA in 1976, even before Biko's death. According to Mbali, however, the mobilisation of progressive anti-apartheid health professionals, both within and outside of South Africa, from the late 1970s and through the 1980s and early 1990s, meant that the WMA 'lost moral authority as a result of being accused of white supremacy and a pro-American engagement in Cold War politics'.

Along with her work published elsewhere that describes how principled anti-apartheid activism laid some of the essential foundations of the tactics deployed by the South African Treatment Action Campaign (TAC) in the 1990s and early 2000s, and then in turn, how the TAC's own 'moral legitimacy ... enabled international health movements to effectively push for new models of global health diplomacy and governance', ${ }^{36}$ in this article Mbali obliges us to continue to insist that 'medicine' and 'politics' are never hermetically separated practices. Nor do they function within the boundaries only of national states, but, rather, "that the history offered in this article... (demonstrates) that transnational civil society actors must remain permanently vigilant to ensure that justice prevails in cases where physicians are accused of human rights violations'.

If the human rights violations of apartheid victims are at least, broadly speaking, relatively well known in the international literature, less openly discussed are the prejudices, discriminatory practices and stigma shown towards health-care workers within their own profession. Carla Tsampiras's article, 'Two Tales about Illness, Ideologies, and Intimate Identities: Sexuality Politics and AIDS in South Africa, 1980-1995', drawn from her $2012 \mathrm{PhD}$ dissertation, ${ }^{37}$ brings such attitudes, practices, and their tragic consequences, into view.

Indeed, 'Two Tales' does three important things in the context of this collection. First, like Mbali (and Denis - see below) it brings our historiography into the more recent past, into the 1980s and 1990s. Second, it brings out into the open the blatant homophobia within South Africa's medical profession of the time that failed to heed the signs and thus

\footnotetext{
${ }^{36}$ Mbali, South African AIDS Activism and Global Health Politics, op. cit. This quotation is from http://panmac millan.bookslive.co.za/blog/2013/05/22/mandisa-mbali-examines-the-history-of-the-tac-in-south-african-aids-a ctivism-and-global-health-politics/ (last accessed 6 January 2014).

37 Carla Tsampiras, 'Politics, Polemics and Practice: A History of Narratives about, and Responses to, AIDS in South Africa, 1980-1995' (unpublished PhD thesis: Rhodes University, 2012). A full copy of the thesis is available on Academia.edu at www.academia.edu/2907679/Politics_Polemics_and_Practice_A_History_of_Narra tives_about_and_Responses_to_AIDS_in_South_Africa_1980_-_1995\#1.
} 
work to avert an oncoming plague of terrible proportions. And, third, it has forced us, as historians of medicine and in our own private capacities, to consider the reproduction in this special edition of photographic images of people having sexual intercourse and with images that have graphically striking - and intentionally shocking - messages.

Ostensibly a 'micro-history' based on a series of interviews with two white healthcare professionals who are gay (physician Dennis Sifris and clinical psychologist Pierre Brouard), these histories are undoubtedly representative of the experiences of many others, in South Africa and elsewhere. Moreover, Sifris, Brouard and others were able - to the extent that they did succeed in drawing attention to HIV/AIDS in the 1980s and early 1990s - to forge alliances and learn from international AIDS activists.

As had been the case in the UK and the USA, "influential medical practitioners and scientists, and politicians responsible for addressing AIDS in South Africa focused attention on this understanding of homosexuality and in doing so rendered invisible heterosexuals, lesbians, bisexuals, transgendered and intersexed people and linked male homosexuality only to whiteness'. Yet, local sexuality organisations had their own political concerns and addressing HIV seemed in the early 1980s to be a less pressing concern than contesting apartheid-related legislation. Sifris was one of the first South African medical researchers to take HIV seriously.

In 1985, being one of the first and most experienced 'AIDS researchers', Sifris was invited to become a member of the Department of Health's Advisory Group on AIDS. Subsequently, however, and in a statement that is as breathtakingly repugnant today as it was then, he was told "that he "unfortunately" could not join because he belonged to a "high-risk group" and ". . if we have a gay man on the (AGA) we have to have a prostitute, we have to have a Haitian, and we have to have a black..."'. Rejected by the state, and along with a handful of other committed individuals, Sifris went on to form some of the earliest anti-AIDS civil society organisations.

Tsampiras' narratives cover the difficulties of such organisations seeking to find common ground and tactics under oppressive apartheid conditions as well as in the face of official antipathy. These are of importance and interest to historians seeking to understand South Africa's immediate pre- and post-apartheid medical histories, and how they overlapped in some ways with those of the USA, say, but also how local dynamics served to constrain and mould some specific aspects of South African responses to the pandemic. Even into the late 1980s, Sifris's medical research, his work in caring for $\mathrm{HIV}+$ patients and his invaluable input into slowly forming government health policies, for example, were being rejected because of his sexual orientation. As Tsampiras movingly relates, this exclusion of Sifris and of other gay doctors' early attempts to ward off HIV/AIDS surely led to many unnecessary deaths, and personal loss.

Pierre Brouard's narrative and recollections combine in interesting ways, the 'voice of the patient' (or the potential patient) so often called for in medical histories and that of the professional. He related to Tsampiras just how fraught the epidemic has been experienced for an individual's sense of self as a 'healthy sexual being'. Contestations of these stereotypes by gay and sexuality organisations became, necessarily, more pressing and more overt. They also defied the state's somewhat prim, unrealistic and conservative public health messages that AIDS could be beaten as simply as 'ABC', i.e. citizens were to 'Abstain, Be Faithful and Condomise'. Instead, the loose consortia of sexuality organisations skirted around or even flouted South Africa's very stringent anti-pornography legislation and produced popular literature aimed specifically at gay 
men and lesbians, who were adults who could choose to have sexual intercourse without necessarily contracting a deadly disease. These images - some of which are reproduced in this journal - '.. . delivered unabashed information about anal sex, oral sex, thigh-sex and mutual masturbation'. Other safer sex images showed black and white men kissing and in sexual embraces, acts that were criminalised for even heterosexuals in South Africa until 1985. These were therefore courageous campaigns that ran the risk of individuals such as Brouard being prosecuted under several repressive laws. It is entirely possible, however, that these portrayals of real human beings engaging in sexual intercourse and intimate physicality and emotionality had far greater impact - and led to more safer sex practices than the state's ABC programmes.

Although 'Two Tales' ostensibly ends in 1995, by which time the profile of the epidemic had changed as HIV/AIDS had become predominantly heterosexually-transmitted and the majority of those living with the virus were black, the legacies of that time period can be felt today. To be gay in South Africa can still be dangerous, as the ongoing practice of 'corrective rape' shows. ${ }^{38}$ Also, as Brouard remarked to Tsampiras, there is an ongoing irony that '.. state resources for AIDS programmes amongst LGBTI communities were not available either during or after apartheid'. These state resources of course now include the widespread availability of ARVs, in which is possibly the largest rollout of medication for HIV in the world. This programme has apparently already begun to reverse the decline in life expectancy amongst South Africans and people are living longer and healthier lives.

But, the history of AIDS is not yet over. Life-long compliance in taking the medications is one concern, as of course is the stability and continued efficacy of the medications until (if?) a vaccine may become a reality. But, has prejudice towards those living with HIV lessened over the short time period during which ARVs have become state-supported and relatively widely available? If we are learning more and more about the history of AIDS, might we yet dare to consider a post-AIDS era, and post-AIDS historiography? For, as many historians of rapidly spreading infectious diseases have noted, epidemics are by their nature attention-grabbers, for historians, as well as for others, and it is with HIV/AIDS that much of the Southern African medically related literature has been concerned for almost two decades now. To paraphrase Shula Marks's famous question 'What is colonial about colonial medicine?' we might ask 'What might be post-AIDS about South Africa's postAIDS historiography?'. ${ }^{39}$

It is far too early to say, but our final article in this collection begins to open the door to such questions. It is authored by Philippe Denis, theologian and historian of Christianity, with Nokaya Makiwane, founder member of the Sinomlando Centre for Oral History and Memory Work on the Pietermaritzburg campus of UKZN. Over the past twenty years, Sinomlando's work has expanded in related directions in several African countries: oral history projects, including of African women clergy and women traditional leaders, and of those caught up in KZN's civil violence of the 1980s; memory boxes made with orphaned children; the training of counsellors; and working with disadvantaged and disabled children to record their histories. Their rich archive of oral testimonies will be an immensely important resource for future historians, and are kept at UKZN's Alan Paton Centre and Struggle Archives, again in Pietermaritzburg.

The paper published here, 'New Patterns of Disclosure: How HIV Positive Support Group Members from KwaZulu-Natal Speak of Their Status in Oral Narratives',

\footnotetext{
38 Amongst many other articles, see 'Corrective Rape: Lesbians at the Mercy of Powerless Men', http://mg.co.z a/article/2013-07-15-00-violence-against-black-lesbians-is-a-struggle-for-power (last accessed 6 January 2014).

${ }^{39}$ Marks, 'What is Colonial About Colonial Medicine?' op. cit.
} 
arose from a project the majority of the interviews for which were conducted by isi-Zulu-speaking graduate student Ntokozo Zitha, under the auspices of the Sinomlando's 'Memories of AIDS Project' in 2011. Focusing on a number of members of 'Fountain of Life', a local Christian support group for people living with HIV, the researchers were interested in exploring the 'representations and emotions associated with disclosure (of one's HIV status) and stigma ... seven years after the start of South African government's ARV roll-out programme...'.

It is an important project and although as yet not complete, the questions raised are significant for a number of reasons. First, the stigma of being HIV + has been seen as one of the most important factors in the apparently uncontrollable contagion of AIDS during the 1990s and early 2000s in particular. Second, since several historically-oriented analyses have been influential in arguing that Christianity and its reformulations of precolonial African sexuality combined with indigenous African belief systems that have themselves become syncretic forms of Christianity, but which continue to understand illness in terms of witchcraft or (or, perhaps, and/or) sin, the interviewees' perspectives on sin, self and salvation are also of interest. ${ }^{40}$

Third, patriarchally-dominated South African societies have continued to - in the words of respected anthropologist Susanne Leclerc-Madlala - 'demonise women' as vectors of the poison or pollution of AIDS, with highly negative consequences for their power to negotiate for safer sex practices. ${ }^{41}$ Interestingly, Denis' article shows that in HIV support groups today, it is women who often take the leading roles, and who are able to disclose and discuss their status more freely.

While clearly underscoring that stigma and discrimination have not disappeared, or that biomedically-based explanations of the origins and cause of infection have suddenly and completely displaced understandings of the origins and - perhaps more importantly, the meanings - of HIV/AIDS, based in other belief systems, Denis indicates that this research project may indicate that ' . . the wider availability of ARV treatment, the ensuing reduced fatality rate and the increased number of people, including men, who receive counselling and testing, may mean that HIV/AIDS is less stigmatised and that disclosure has become easier...'. Moreover, the interviews Denis and Zitha have done suggest the possibility that people living with HIV now have a better 'language to express the[ir] emotions and feelings associated with HIV/AIDS' than those from a decade ago, whilst growing assertiveness amongst women in relationships with men have encouraged greater disclosure and undermined stigma.

The later sections of 'New Patterns of Disclosure' show convincingly that there are an increasing number of spaces where disclosure of one's HIV status can be achieved in a supportive way; and that within these spaces a refashioning of ideas of theology and of sickness and even of attitudes towards biomedical ARV treatment regimes is beginning to take place. Even as the enduring structural factors of social, economic and gender inequality will continue to be the stuff of post-AIDS histories in South Africa, as Denis concludes: 'As the epidemic enters its fourth decade, it becomes increasingly clear that it is accompanied by profound changes in matters of gender, beliefs and interpersonal relationships'. This is fervently to be hoped for, though historians may be less sanguine in recalling the endurance of tuberculosis and the structural forces that create the conditions

\footnotetext{
40 The literature is well covered in the article, but see especially Peter Delius and Clive Glaser, 'Sexual Socialisation in South Africa: A Historical Perspective', African Studies, 61, 2 (2002), 27-54.

${ }^{41}$ Suzanne Leclerc-Madlala, 'Demonizing women in the era of AIDS: an analysis of the gendered construction of HIV/AIDS in KwaZulu-Natal' (unpublished PhD thesis, University of Natal, 1999).
} 
for poverty and ill health. As Howard Phillips had noted on the first morning of our meeting, 'in the three days of this workshop nearly 2000 locals will die of AIDS-related causes'.

\section{Conclusions and future directions}

After our workshop ended, we felt that the goals we set for ourselves had largely been achieved. We had brought a number of leading local and international historians and students of healing, health and medicine into closer contact, and encouraged vigorous discussion of their current work in an African region. Discussions were also begun about the possibility of other scholars from that August group, taking the workshop initiative forward, perhaps on a biennial basis, if local historians are permitted to commit their time to the logistical planning and funding. Reflecting on the current state of South African medical historiography, we are convinced that amongst this small community of scholars, and following in the footsteps of those whose opposition to colonialism, imperialism and apartheid, was achieved through their trenchant scholarship, there is a great deal of vibrancy and passion driving our research, and that as historians there is much we have yet to contribute. As the brief overviews of topics covered at the NDHHHMAC in this editorial demonstrate, some scholars are refining studies of more established medical history themes, while others work on researching lesser known themes, as well as using interdisciplinary techniques. Development of collaborative research projects, some of them transnational in nature, are also bringing scholars with different backgrounds and skill sets together in productive engagements. It is also extremely encouraging that, more medical histories are being produced in Africa by those based in African History departments than ever before.

Nonetheless, despite the many positive outcomes of these recent scholarly exchanges, we close this editorial with a number of points for further contemplation and, hopefully, action. First, to reiterate Howard Phillips' call, many significant gaps in the broader medical history field remain to be explored. Second, as South Africanist medical history scholars, we need to continue to engage with the broadening focus of research areas. As eminent medical historian of Africa, Nancy Rose Hunt, argued in a keynote address at a conference on health-care in Africa, in Basel, Switzerland, in 2011, we are entering a 'significantly new era of producing medical histories of and for Africa', one with neoliberal economies and new IT technologies that make our world seem like a much smaller place. Hunt asserted that as scholars, "we are now in a time of "global health", and we must reckon with this new creature and nomenclature head on. . . (as) it has implications for how we conceptualise and cast our historical work' ${ }^{42}$ Here we might add that those scholars based in the Global North but whose 'field-work' is carried out in the Global South have new digital opportunities to make their research accessible and affordable for African libraries and individuals, an ethical responsibility that has often not been honoured. ${ }^{43}$

\footnotetext{
${ }^{42}$ Hunt, 'Suturing New Medical Histories of Africa', op. cit., 34.

43 Many of the monographs we cite in this editorial are not available to purchase in South Africa - let alone in the poorer regions of our continent - and given the shrinking university library budgets, are unaffordable even at the wealthier universities in Africa as hard copies. Institutional access to international journals is patchy. Our own institution for instance - which has five campuses and includes a major Medical School - subscribes to neither Medical History nor the Social History of Medicine. Daniel Pearce of Cambridge University Press kindly shared this information 'We currently have 2353 active subscriptions recorded for Medical History from institutions on the African continent. We included the journal in our aid agreement with HINARI (a partnership between several major publishers and the WHO which aims to enhance global access to medical research). These
} 
Third, while the 2012 workshop successfully built stronger links, international scholars have tended not to be from African countries north of South Africa's borders, but from Europe, the UK, Canada or the USA. Hence, the skewed nature of present networkbuilding activities that needs to be rectified when future exchanges are arranged. In addition, one apparently simple logistical issue - that of finding a mutually convenient time for workshops - often proves disproportionately challenging when academic terms are inversely timed in the different hemispheres. On the other hand, with a view to rooting future workshops in the Southern African region, yet maintaining international connections, Southern African-based scholars can show more initiative in holding their own workshops in alignment with the broader Southern African Historical Society and Historical Society of South Africa's conferences, which occur in alternate years, usually in the Southern hemispheric winter.

Fourth, the dominant focus on South African regional histories needs to be expanded to incorporate a greater number of papers on research topics from other African countries. To decentre South African medical history topics from regionally- or continentally-based conversations, will certainly lead to valuable insights emerging. ${ }^{44}$

Of course, many of these challenges boil down to financial disadvantages that restrict the mobility (and, thus, participation) of researchers based in sub-Saharan African regions, and marginalise their research. ${ }^{45}$ We need therefore to work on building stronger international networks and research links with medical historians across Africa and farther afield. We ourselves could also do far more in making our voices as historians more audible in African public fora - in the media, in public lectures, in contributions to state calls for input on archival legislation, and through working with those in the heritage sector to destabilise the ongoing dominant narratives of South African history that focus only on political heroism and racialised identities, for instance. We need, through our teaching, to insist upon the centrality of histories of medicine, health and healing to our pasts, in our present and in our future.

Finally, for some time to come it is certain that within the African continent, material and organisational challenges to building professional networks will continue, perhaps even becoming more intense. New medical history innovations can sadly be extinguished with great rapidity without adequate institutional support. In this context, building and maintaining a community of individuals interested in carrying out research on the history of health and medicine in Africa is vital. The many efforts occurring in South Africa in inter-disciplinary programmes with international partners, to build up a larger group of young Africa-based graduate students and researchers, must be supported within History programmes with the African academy too, by giving due intellectual and financial

institutions are able to subscribe at heavily discount rates (almost free), and gain perpetual access to Medical History content online.... (However) As circulation in Africa is dominated by the HINARI aid deal the gaps tend to be, perversely, in the wealthier regions. South Africa only has 15 institutional subscribers and Egypt none, for example, whilst Ethiopia has 176, Tanzania 179, and the DRC 117. We have subscriptions from also every country in west, east, central and the horn of Africa. Coverage in the south is comprehensive but for South Africa. Coverage in the north is somewhat lacking, with no subscriptions in Algeria, Egypt or Libya. We do have a reasonable number in Morocco and Tunisia'. (Email correspondence, Pearce to Parle, 3 October 2013.) Given the institutional weakness of the historical profession across the continent, what is intriguing is: who is paying for and accessing Medical History online? Moreover, individual subscriptions are often not possible since international banking snafus mean that PayPal and similar payment portals from African countries are simply disallowed.

44 Digby, 'The Medical History of South Africa', op. cit.1195.

${ }^{45}$ Schumaker, 'History of Medicine in Sub-Saharan Africa', op. cit., 276-9. 
recognition to the value of historically informed analysis. As the last twenty years in South Africa has clearly shown, there can be no doubt that there will be a continued need for African historians to keep on 'speaking history to power'.

\section{JULIE PARLE, VANESSA NOBLE}

Historical Studies, School of Social Sciences, University of KwaZulu-Natal, PO Box X01, Scottsville, Pietermaritzburg, 3209, South Africa

Email: parlej@ukzn.ac.za,noblev1@ukzn.ac.za 